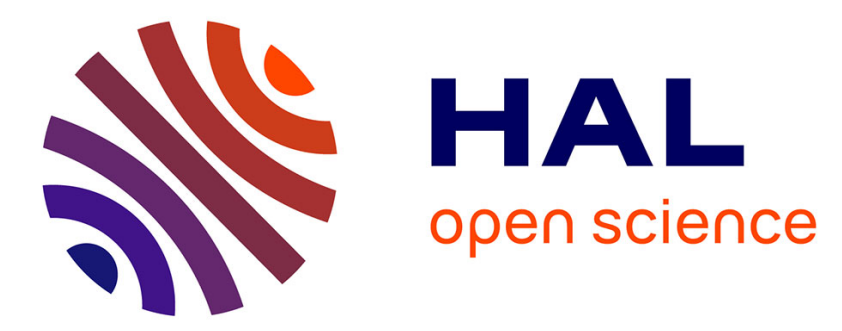

\title{
A merchant or a French Atlantic? Eighteenth-century account books as narratives of a transnational merchant political economy \\ Pierre Gervais
}

\section{- To cite this version:}

Pierre Gervais. A merchant or a French Atlantic? Eighteenth-century account books as narratives of a transnational merchant political economy. French History, 2011, 25 (1), pp.28-47. 10.1093/fh/crq065 . halshs-00635903

\section{HAL Id: halshs-00635903 \\ https://shs.hal.science/halshs-00635903}

Submitted on 25 Jul 2017

HAL is a multi-disciplinary open access archive for the deposit and dissemination of scientific research documents, whether they are published or not. The documents may come from teaching and research institutions in France or abroad, or from public or private research centers.
L'archive ouverte pluridisciplinaire HAL, est destinée au dépôt et à la diffusion de documents scientifiques de niveau recherche, publiés ou non, émanant des établissements d'enseignement et de recherche français ou étrangers, des laboratoires publics ou privés. 


\section{A Merchant or a French Atlantic? Eighteenth-century account books as narratives of a transnational merchant political economy Pierre GERVAIS, University Paris 8 / UMR 8533 IDHE}

On June 1, 1755, an anonymous clerk in Bordeaux merchant Abraham Gradis's shop took up a large, leather-bound volume, containing 267 sheets of good paper, each page thinly ruled in red. The first page was headed by the legally compulsory stamp of approval of an official, in this case provided by Pierre Agard, third consul of the Chambre de commerce of Bordeaux. Agard had signed the volume on May 13, just a week after having taken up his position, and had thus made it fit for use as a merchant record. ${ }^{1}$ Right under this certification, our clerk wrote in large cursive across the page 'Laus Deo Bordeaux ce Prem Juin 1755,' and proceeded to copy the first entry of what was a new account book: a list of all 'Bills receivable,' that is, debts owed his master. This inaugural act, however, went unnoticed, and one would find no mention of it either in Gradis's letters or in the later accounts of historians.

Opening an account book for anybody connected with the market place was a humdrum affair at the end of the eighteenth century, so much so that to this day we tend to take for granted the meaning of such a gesture. What would be more natural than wanting to record one's transactions, customers, and the ubiquitous mutual credit which was a necessary part of commercial life? Merchant practice has given rise to a very vast body of historiography; from the solid baseline provided by the classic studies by Paul Butel, Charles Carrière or André Lespagnol as well as Bernard Bailyn, David Hancock or Cathy Matson on the British side, it has developed into one of the major topics of historical conversation in the past twenty years with the rapid development of the Atlantic paradigm, which gave 'le doux commerce' center stage as the key force behind European expansion, and possibly the organizing principle of what has come to be called the 'Atlantic world'. ${ }^{2}$ But account books have remained on the 
margins of this conversation, perhaps because the very activity they embodied was rather pedestrian in the 1700s. Accounting history has traced the rise of double-entry accounting, a sophisticated method of financial control which was the primary -though not exclusivesource for accounting as we know it today and as far back as the Renaissance.

By the end of the seventeenth century, double-entry was well-known among elite traders, but most accounting was still done in a simpler single-entry system. In this respect, the eighteenth century is better known as the era in which accounting for costs started to develop along with the new, large productive ventures of the early agricultural and industrial revolutions, while, in sharp contrast with ironworks and noble estates, merchant accounting remained primarily concerned with financial transactions. Moreover, outside of a select group of large companies and international traders, which had to innovate because of the complexities of their multinational operations, most eighteenth-century merchants held to practices already well-established in the two preceding centuries. As a result, merchant accounting is largely seen as a rather uneventful branch of commercial life until the rapid spread of new, more elaborate management techniques associated with the Industrial revolution in the nineteenth century. ${ }^{3}$

There is more to Abraham Gradis's account book, however, than this straightforward and whiggish tale of order and progress, for the figures it contains express the underlying mechanics of European mercantile expansion, and thus raise the question of its nature. That European expansion was trade-based is hardly a new idea, but why exactly trade expanded why merchants filled more books with more accounts - is not as simple a question as it sounds. The standard economic approach posits the quasi natural expression of an urge to expand among economic agents, particularly merchants, once the proper institutional environment had been created; secure property rights through limitation of royal power, for instance, or more open institutions through which people would be empowered to escape 
extended family or tribal constraints, generated new incentives for those willing to shed old routines. The discussion thus revolves around the presence of these incentives, while the acquisitive impulse itself is considered a given. Indeed, this view of economic expansion as a natural consequence of new incentives dovetails smoothly with descriptions of the First Industrial Revolution as a set of innovations in the productive sector also enabled through a propitious social-cultural environment. The 'Industrial Enlightenment' generated a new level of incentives and opportunities, freeing yet more energies and imagination on the road to industrial capitalism, but the basic mechanism was the same: homo æeconomicus - usually male in such accounts - saw a new field of opportunities once barriers had been removed. For a trade which promoted market unification and competitive intensification, account books first and foremost represented a recording tool which helped rationalize the decision process, and there is no reason to assume that their analysis would pose any particular challenge. This construction also fits well with a regional and even nationalized view of Atlantic trade, since a generalized economic pattern of growth would take varied local forms, depending on local political circumstances. ${ }^{4}$

But in the past fifteen years or so, scholars specializing in the French Old Regime have started offering a different model, in which they stress the time- and space-specific dimensions of economic activity. In these accounts, European economic expansion followed rules and paths which were peculiar to the Early Modern era. Price-setting mechanisms, for instance, are described as primarily operating in periodic fashion and within regulatory and social limits, with profit itself a result of both experience and anticipation. In this universe, prices could not play the informational and distributive role assigned by modern economists. While progress was possible, it was not a straightforward result of competition and reward, in what were effectively 'priceless markets'. Expansion ocurred not so much by changing prices or 
productivity than by playing on segmented, spatially segregated niche markets, through product innovation more often than not. Profit distribution was dependent on a complex intertwining and hierarchization of activities, embodied in far-reaching sub-contracting networks and cartels. Last, but not least, the transition to the First Industrial Revolution represented a break with past practices, rather than being a gradual evolution of techniques. In this transition, we see trade as a separate sphere with its own rules and own separate developmental process. "Progress" does not necessarily occur, or at least its presence is open to question, because there is no assumption that the system will work to maximize the efficiency of resource allocation. Similarly, the question of whether these processes were heterogeneous, depending on regional variables, or on state, national or local institutions, or whether they were generalized and uniform, is left wide open. ${ }^{5}$

This debate has direct bearing on the analysis of French activity in the Caribbean trade, because depending on which side one picks, it leads to two very different ways of analyzing geographic space and its precise role in the period of 'first globalization. ${ }^{6}$ How was the fact of a French colonial Empire articulated in a more general movement in which trade expanded throughout the colonial sphere? If we accept the idea that the expansion of trade was a direct reflection of a timeless acquisitive impulse on the part of merchants, then the identification of the Caribbean as a separate sphere was primarily a political phenomenon, before being an economic one or even a social one. The creation of French Caribbean markets was consequently a function of royal policies, within a broader frame of market development. Conversely, the segmented and monopolistic character of Early Modern markets leads to the possibility that the French Caribbean islands were a separate market, or even a set of separate markets, deliberately constructed within a broader course of imperial economic development. Royal policy was an acknowledgement of a state of affairs on the ground as much as a 
contribution to it. The present paper questions the very notion of a 'French' Atlantic. The concept of a French Atlantic makes sense in a world structured by the colonial policies of European States. It makes less sense if that world turns out to have been a mosaic of places held together by the bonds of exchange relationships as much as by the bonds of Empire.

This article focuses on the sources of the commercial activity which made the French Caribbean, in particular, Saint-Domingue, Martinique, and Guadaloupe, the pride of the eighteenth-century French Empire. I concentrate on the counting houses of Bordeaux, Nantes and Saint-Malo. In these places, the slave trade was organized and financed, planters were bankrolled, and sugar and other colonial products were brought back to be redispatched throughout Europe. Complex business webs were built to deal with what was arguably the most wide-ranging endeavour devised by economic agents anywhere, but these webs were not designed within a regionalized framework, at least not in the national or imperial sense. Account books left no space for place or borders. Instead, they structured relationships around very different notions of interpersonal credit and risk. This does not mean that the French Caribbean - or more broadly the French Empire - was irrelevant to the way merchants operated. To understand how place and politics interacted with trade, however, we have to understand according to which principles trade was organized in the first place.

Account books provide us with a perfect tool to grasp this organization. Accounting was primarily a way of listing debts and loans, and as such was the most direct expression of the key relation of power in the Early Modern era, that of credit. ${ }^{7}$ It gave this relation its grammar, and underpinned all its manifestations. Each account was a narrative summarizing the interaction between two very specific partners within this very specific universe of credit. The fact that accounting was peripherally concerned with profit calculations or strategic decisions points to the hierarchy of priorities which an actor on Early Modern markets had to adopt in order to be successful; providing credit came first, bottom-line profit was a distant 
second, and cost issues were even farther behind. Within these constraints, merchant activity necessarily transcended both imperial and regional boundaries; it was articulated around the personal, not the political or regional, a fact which is clearly apparent in account books.

Of course, borders did offer avenues for comparative advantage and provided ways to thwart competition from "foreign" merchant networks, just as much as regional, ethnic, or religious kinship ties could be used to reinforceme these networks. The importance of these possibilities was abundantly underscored by the exclusif and by other non-tariff barriers, as well as by the role of kinship in international trade. But regardless of the context in which it was deployed, credit still had to stand for a whole complex of interpersonal links, well below — or beyond - the national or regional level, and only partly quantifiable. As will be demonstrated in the case of the House of Gradis, there is good reason to believe that these links, more than any other ingredient of merchant life, were the defining force behind merchant strategies, and unified the merchant world in ways beyond the reach of all other centrifugal forces. All merchants operated in the same way, assuredly in a very segmented universe, but with a full consciousness of the underlying unity of commercial life. Regions and empires did exist, and did play a role, but their roles were strictly constrained by the rules of merchant exchanges.

Recording transactions in books, in a written manner, was a legal necessity in 'law merchant,' i. e. in the body of judicial decisions which provided precedent and guidance to jurisdictions having to adjudicate conflicting claims among traders. A written record of a transaction, appearing seamlessly as one item among a chronologically arranged series, provided solid proof that a transaction had taken place. This usage, already nearly universally enforced by customs in Western Europe, became a legal obligation in France with the Ordonnance de 1673. Knowledge of accounting came first in the list of skills one had to have 
in order to bear the title of Master merchant (Title 1, Article IV); a compulsory balancing of accounts had to take place at least every year between parties to a contract (Title 1, Articles VII and VIII); and a whole, though rather short, chapter was devoted to the issue of books (Title 3, 'Des livres et registres des négocians, marchands et banquier'). As with merchant law, however, recording daily transactions in order was enough; what was required was a 'journal' or 'daybook', containing 'all their trade, their bills of exchange, the debts they owe and that are owed to them, and the money they used for their house expenses,' and written 'in continuity, ordered by date, with no white space left' [between two transactions]. ${ }^{8}$ Any calculation above and beyond this simple act of recording was unnecessary.

Admittedly, well-kept accounts were useful whenever they had to be balanced, in the case of a death, a bankruptcy or the dissolution of a partnership. But 'useful' did not mean 'necessary,' and it is hard to believe that generations of merchants would have filled endless volumes with tiny figures simply to spare some work to their creditors or executors. In truth, with a well-kept journal, the work of ventilating operations between accounts to calculate the balance on each of them could be postponed until it became necessary. And it was not necessary as often as one would think: the Ordonnance de 1673 quoted above prescribed compulsory settlements of accounts every six months or year, depending on the kind of goods traded, which implies that left to their own devices, traders would not necessarily have bothered to settle accounts every year — and indeed the book with which we started, Gradis's June 1755 journal, shows no trace of balancing the accounts all the way through to $1759 .{ }^{9}$ Even the most elaborate form of accounting, namely, double-entry accounting, was seldom used for calculating profits and helping managerial decision.

In the absence of standardized production and enforceable norms of quality, each transaction was largely an act of faith on the part of the buyer. After all, the buyer was almost never enough of an expert on a given product to be able to detect hidden faults and 
blemishes in quality. A trader was thus at the mercy of his suppliers for the quality of his goods. The problem was identical for sales, since large merchants had to sell at least part of their goods through commission merchants living in far-away markets. These agents alone could gauge the state of a local market and maximize the returns of a sale; their principal could simply hope that his trust was not misplaced. Moreover, the slow flow of imperfect information meant that markets for any product could fluctuate wildly, suddenly and unexpectedly, so that even a venture with the best suppliers and the most committed selling agents could come to grief. In the last analysis, forecasts were at best guesswork, past experience was not a useful tool for short-term predictions, and the valuation of each good was the result of an ad hoc negotiation entailing both an informed decision on the value of each particular good -this piece of cloth, that barrel of port- and a bet on the market prices at the future moment of the eventual resale. ${ }^{10}$

If a simple record of transactions was enough to fulfill legal obligations, and more complex records were not necessarily very useful for profit calculations or to help the decision-making process given the shifts in markets and the uncertainties in supplies, why then were such records kept at all? To answer this, one has to understand what was recorded — and here we turn back to our Bordeaux merchant, Abraham Gradis, and his account book. ${ }^{11}$ Parts of this book, and elements of the preceding one, for 1751-1754, were analyzed for the purpose of this paper, in order to get a quantitative grasp on what kind of operation was recorded. ${ }^{12}$ Gradis was an international trader, active in the French colonies. Much of his activity consisted in sending supplies to the French Caribbean and Canada, and importing colonial goods in return. As a Jewish trader, he could not at first own plantations directly, but maintained an extensive network of correspondents in the colonies. In Gradis's books, 217 persons or families owned an account active between October 1754 and September 1755. Out of these 217 people or kin groups, 54 can be geographically located through a specific 
reference in the books. Ten of them lived in Martinique, Guadeloupe and Saint-Domingue, including the Révérends Pères Jacobinss and individuals from well-known planter families. There were another seven correspondents in in Quebec, including François Bigot, intendant of Nouvelle-France -an official connection which would land Gradis in the middle of the Affaire du Canada after 1760, when Bigot would be accused of corruption. Of course, with 75 percent of the accounts not identified, one can easily assume that Gradis's network included significantly more correspondents in the French colonies than the few I could identify. ${ }^{13}$

A list of business relations does not make an account book, however; what is really significant is what Gradis did with it. Personal accounts were the most numerous by far. To the 217 clearly personal accounts (individuals, families, institutions like the Jacobins or semiofficial accounts for "The King," "Intendant Bigot" or "Baron de Rochechouart") must be added seven opened for unspecified partnerships ("Merchandize for the Company") or for commission agents ("Wine on account with X"), and an extra 15 covering ship ventures ("Outfitting of ship X ", "Merchandizes in ship Y"), which were at least in part also partnership accounts. Overall, a least 225 of the 266 accounts which appeared between October 1754 and September 1755 can be classified with absolute certainty as personal accounts. Each of these personal accounts created a relationship between Gradis and the individuals concerned very much like that of a bank with its customers, except that the credit which was extended was apparently mostly free of charge and interest.

For instance, the following posting:

Mr La Roque à Versailles Dt, a Divers £ 2176.16.6 pour 60 demy Barriq. Eaux de vie envoyées p Son Compte à Quebec par le N.re Le st Fremery de st Valery Suivant Le Livre de factures a fo 136 Savoir à Eaux de Vie pr 19 p. Cont. en 6 Bq 970 V.£ 1864.11.6 à Caisse pour tous fraix deduit le montant des pieces vuides 232.5 à Primes d'assurance p £ 2000 à 4 p Ct $80^{14}$

essentially meant that in the account 'Eaux de vie,' i. e. Gradis himself, had sent 2,176 Livres tournois worth of spirits for the benefit of Mr. La Roque, and no payment had been made by the latter. Indeed, no payment was made for the rest of the summer, and probably no payment 
would be made until the spirits were sold. The net result was that Gradis had loaned this amount of money to La Roque for several months, with no apparent charge or interest. Conversely, when Gradis's clerk wrote the following:

Caisse Dt à Dupin £ 2712.3 pour du Sel qu'il à Livré en 1754 p le navire L'Angelique et pour le Cochon envoyé a la Rochelle p le n.re L'entreprenant dont nous debitons La Caisse, en ayant été Creditée ${ }^{15}$

he was recording that a Mr. Dupin had generously loaned almost 3,000 Livres tournois worth of salt to Gradis for anywhere between six months and a year and a half; this sum had been received in the 'Caisse,' that is, paid over in cash to Gradis, for salt which had been given by Dupin - but Gradis had not paid his debt to the latter, and, again, no interest or charge was listed. Last but not least, two credits could cancel each other:

Mr Darche Dt. à Mlle de Beuvron $£ 2446.5$ pour une année de la rente qu'il doit a lad.e Dlle ${ }^{16}$

meant that the corresponding sum was transferred to Mademoiselle de Beuvron on Gradis's books, to be offset by sums she owed him, while he would take charge of recovering what Darche owed in the course of his business transactions with him.

This book credit was the dominant form of payment in Gradis's accounts, as it may well have been the case for all traders everywhere. Payment could be made with metal currency, or with commercial paper, promissory notes and bills of hands ranging from the time-honored international letter of exchange to the more modern note of hand, a simple I.O.U from one individual to another. If currency was used, then the 'Caisse,' or cash box, would be listed as receiving or disbursing the corresponding sum; though sometimes, for obscure reasons, commercial paper found its way into the 'Caisse,' which undermined its very purpose. ${ }^{17}$ If commercial paper was used, it would be listed as 'Lettres et billets à recevoir' or 'Bills receivable,' that is, paper debts from others to be cashed at some point, or 'Lettres et billets à payer,' or 'Bills payable,' I.O.Us manifesting that some money had been borrowed and would have to be reimbursed at some point. Complex rules governed interest rates and 
the period of validity of such paper debts, but the important point here is that these debts were always listed separately, in the relevant accounts. This makes possible a quantitative analysis of the use of currency, commercial paper and book credit over the period studied.

We focused on 89 personal accounts from June-August 1755, having discarded accounts with ambiguous titles, or belonging to Crown officials, to Gradis family members, or to partnerships to which Gradis probably belonged, such as 'Les Intéressés au Navire L'Angélique.' 18 This gave us a set of individual or partnerships to whom 'normal' credit, not influenced by personal proximity or official status, would be extended. The results, as shown in Figure 1, are very clear: even for a major international trader like Gradis, in a European commercial port flush with metal currency, book credit was the main tool of business. Even if we count as 'Cash' transactions all exchanges of commercial paper for cash, the share of credit instruments compared to hard currency in transactions around the Gradis firm reached a hefty 72 percent. $^{19}$

The volumes involved in these transactions were impressive. Because the 'Bills receivable' and 'Bills payable,' that is, the formalized credit and debt accounts, were balanced at the beginning of June 1755, we know that at that date Gradis held 671,117 Livres tournois in IOUs from various people, and owed to dozens of creditors an equally impressive 430,072 Livres tournois, also in formalized paper IOUs. Considering the proportion of book debt to formal debt, over 2 to 1 , generated in the next three months, book debt in toto may have amounted to well over two million Livres tournois... The larger accounts may have borne interest; one Jacob Mendes had his account balanced, and the clerk recorded the following:

Jacob Mendes cte: Vx: a luy même ct N.au $£$ 67167.15.5 pour Solde Compte Regle ce Jour en double, dont les Interets Sont Compris Jusques au 1er Courant ${ }^{20}$ 
But four other personal accounts were balanced between June and August 1755, with no

mention of interest. There is no such mention either in the numerous instances where errors were discovered, and accounts rectified, sometimes months after the error was made. ${ }^{21}$

Fig. 1: Value of transactions by means of payment used for personal accounts in the Gradis firm, June-Aug. 1755 (in percent of the total value of transactions for each type, in livres tournois. Crown officials and ambiguous accounts excepted)

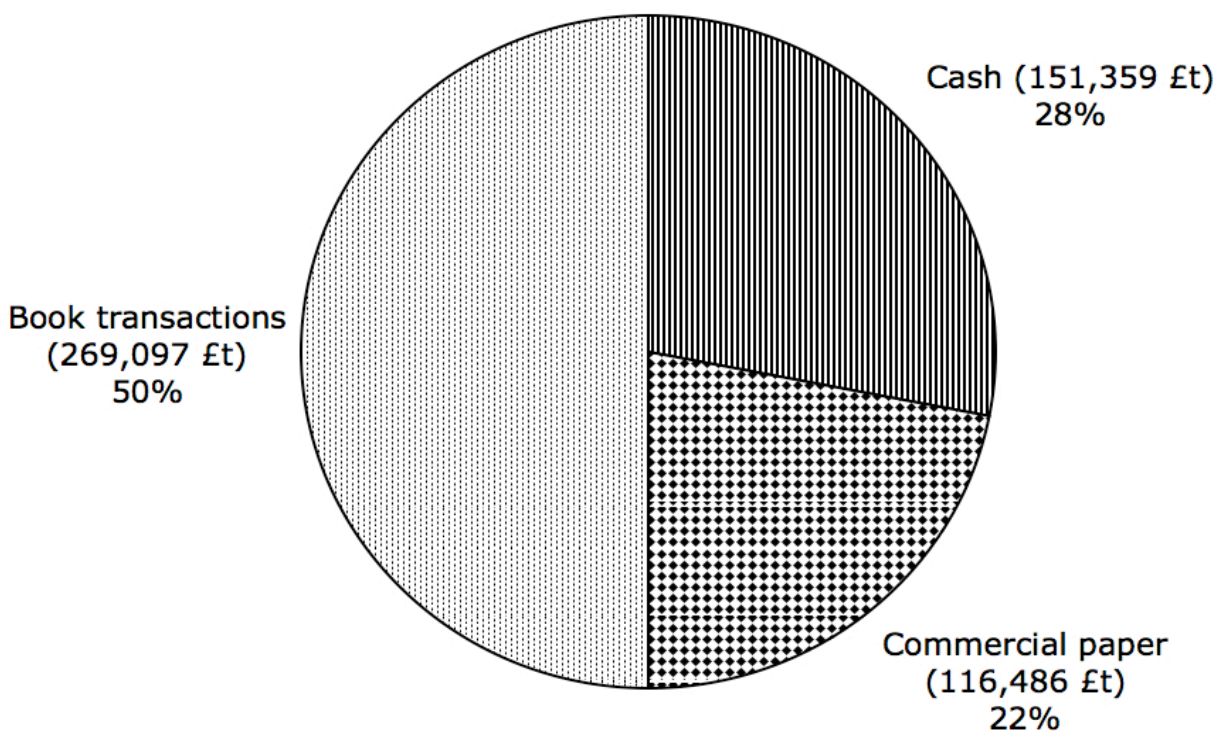

Source: 181 AQ T*, loc. cit. Only transactions involving one of the 89 personal accounts selected were used. Transactions involving 'Caisse' were totalled first, then transactions involving any commercial paper account. Book credit $=$ all other transactions, eliminating double postings, all profit and loss postings (equivalent to the total or partial closing of an account), and subtracting any payment from or to the same account within two weeks (equivalent to a payment on the spot, recorded with some delay; quick payments of that type represented barely over 40,000 Livres tournois, less than 10 percent of all payments).

The figures above only refer to the business Gradis was doing with the individuals and groups who held accounts with his firm. A complete analysis, including purchases and sales listed directly in Gradis's own accounts, which were all commercial paper-related operations, as well as credit extended to Crown officials, gives a different set of figures:

Fig. 2: Value of transactions by means of payment in the Gradis firm, June-Aug. 1755

(in percent of the total value of each type of transaction, in livres tournois) 


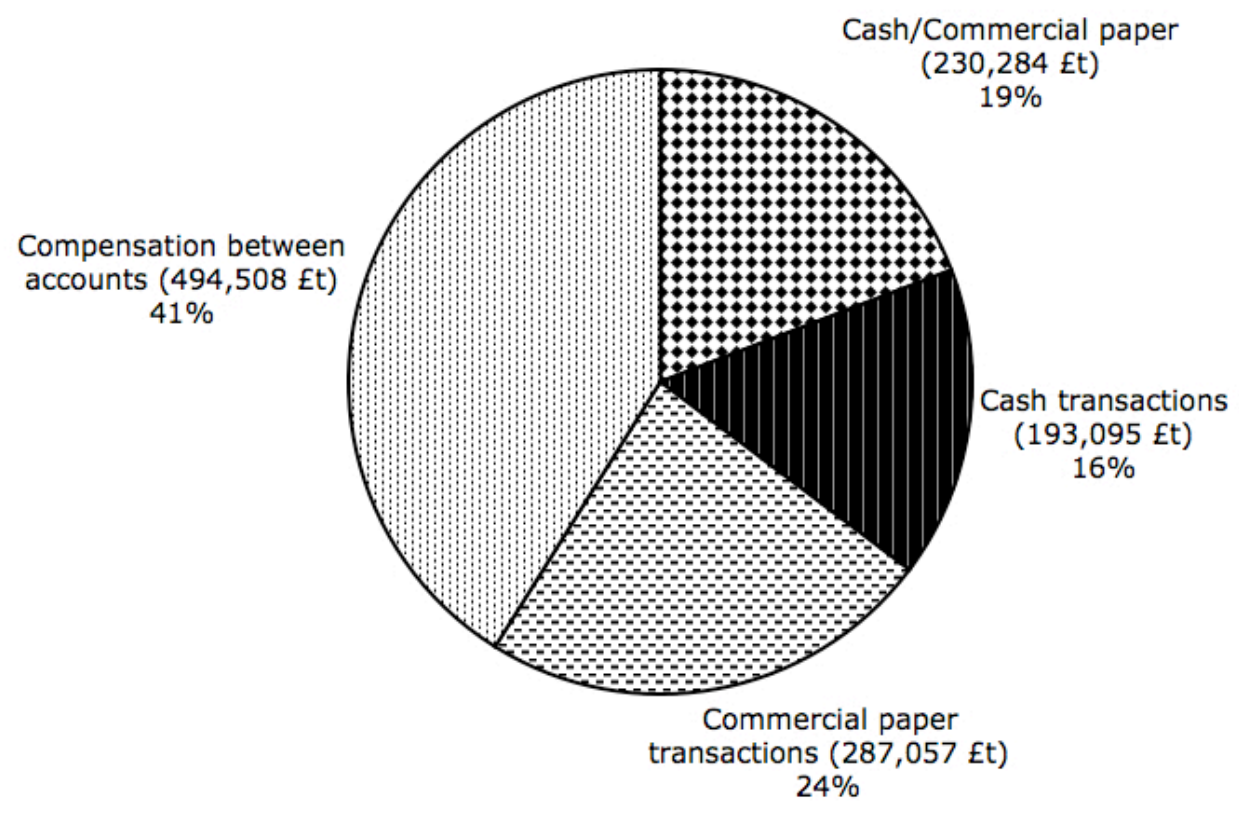

Source: $181 \mathrm{AQ} \mathrm{T}^{*}$, loc. cit. All transactions included except all profit and loss postings (equivalent to the total or partial closing of an account), and transfers of already acquired assets between Gradis's own nominal accounts, e. g. 'Marchandises envoyées à Quebec pour n/C dt à Marchandises générales' or 'Indigos pour n/C dt à Primes d'assurance.' Such operations meant only that goods listed by Gradis under his general merchandise account were transferred to a narrower merchandise account, or that money he had already paid for insurance was transferred from a special insurance account to the account of the merchandise for which insurance was paid. In both cases, no value changed hands, and the posting was simply a reorganizing of the classification of assets in a slightly different way. However, I included transactions when one of the accounts involved could be a partnership account, e. g. Marchandises pour la Cargaison $n^{\circ} 7$,' which was differentiated from 'Marchandises pour notre Compte' and was therefore almost certainly a partnership account; in such cases value was indeed transferred between Gradis and the partnership involved. Note that since transactions involving both cash and commercial paper were included, I had to create a new category.

Cash transactions represented over a third of all transactions in value. Over half of these cash movements went to the purchase and sale of commercial paper; straight cash purchases or sales represented 16 percent of all transactions in value. Even including all movements between cash and commercial paper accounts, book compensations still made up over 40 percent of all the volume of trade in the Gradis firm, proof that personal credit flows were allimportant. Indeed, commercial paper itself was nothing else than formalized credit, and if we exclude the complex category of transactions mixing commercial paper and cash, we end up with over 80 percent of all transactions being made on credit. 
Last but not least, cash, commercial paper and book credit were not equivalent means of payment. Leaving aside transactions involving both cash and commercial paper, it is possible to observe how each type of payment was used in terms of the value of the transactions involved:

Fig. 2: Proportion of transactions by means of payment and value of transaction in the Gradis firm, June-Aug. 1755

(in percent of number of transactions for each category, $\mathrm{n}=128 \mathrm{cash}, 41$ commercial paper, 107 compensation between accounts)

Cash

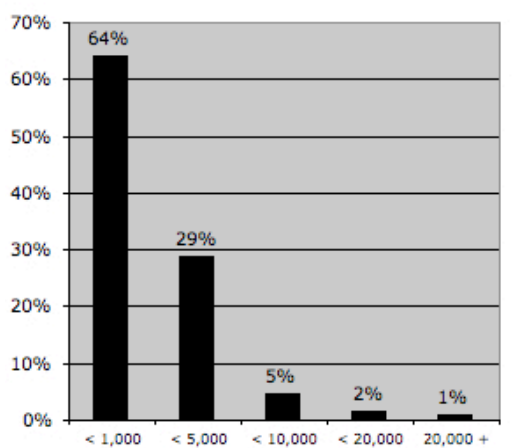

Commercial paper

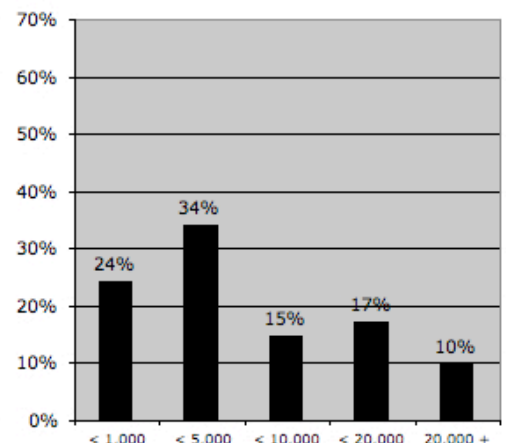

Compensation between accounts

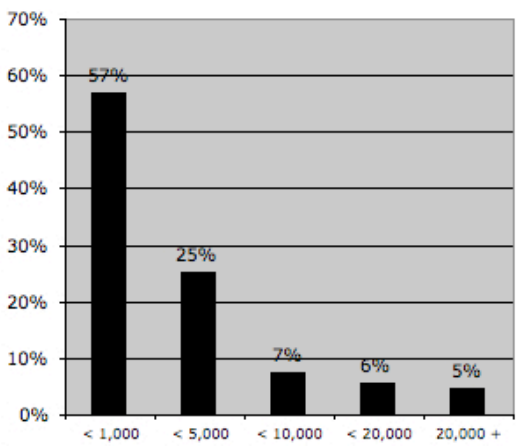

Source: 181 AQ T*, loc. cit. The transactions included are the same as in Figure 2, q. v.

These graphs show again that book accounts were used as much as cash, and in much the same way. Obviously these book credits were not as liquid (that is, easily convertible without loss of value) as cash, since they could circulate only within the circle of individuals and groups having themselves accounts with Gradis. But on the other hand the volume they represented was actually much higher than the volume of cash used by the firm, which is another way of saying that transactions took place mostly within this circle of known partners. Moreover, book accounts could also, in special cases, comprise much larger amounts, otherwise usually dealt with through commercial paper.

Thus our opening caveat: accounts and account books were not straightforward tools of analysis. Opening an account was tantamount to creating a special bond of partnership, which explains why whole aspects of a traders' activity were lumped together in nondescript general accounts, while apparently small transactions could give rise to specific accounting efforts. 
Because the core distinction was between direct partners and all others, issues of costs and profit were only dealt with peripherally, if at all; at the very least, they were clearly subordinate to this higher, primary boundary between the inner circle and the rest of the world. The same held true for national loyalty, regional proximity and all other parameters of interpersonal relationships. While they could play a role in specific cases, there is no indication that account holders could be neatly dumped into one of these categories. What made a business acquaintance into an account holder was the logic of the credit network, a network at the centre of Gradis' strategy.

Almost all the non-personal accounts were also credit-centered, in much the same way as personal accounts. Gradis, our Bordeaux merchant, practiced a sophisticated system of double-entry accounting, which allowed him to develop two types of accounts on top of personal accounts. Parts of his inventory, a handful of goods which he traded in most frequently, were granted specific accounts: sugar, wine, indigo, spirits, and flour, thus appeared as separate accounts, debited with incoming merchandise, and credited when the goods were sold. To these, should be added accounts such as Cash and Bills payable and receivable, which also contained assets. Then, there was what accountants would call today 'nominal' accounts such as Profit and Loss and expense accounts. These accounts were supposed to summarize in the final balancing of all accounts (which almost never took place) the status of the capital expended, which had been neither invested in inventory, nor loaned out as a book debt. In practice however, most real accounts, and even some apparently nominal accounts, were much closer to personal accounts than one would expect, since they, too, were meant to encapsulate a certain credit relationship with a certain group of partners. 
Let us start with an example: an account called 'Indigos p. Compte de Divers' included all indigo traded on commission. This made sense only if the discriminating principle was a combination of both the type of principal/agent relationship established by Gradis as a commission merchant with the people who commissioned him, and of the specific product concerned. Gradis's accounts could not readily provide an analysis of the benefits made on indigo in general, since there was a separate 'Indigo' account. Indeed, another account of the same type was 'Sucres et caffés p Cpte de Divers,' which mixed two vastly different products, proof if need be that the issue was not the products themselves. ${ }^{22}$ There was no way either to calculate the commissions Gradis received from each principal he was commission merchant for, nor on each merchandise, since all commissions were dumped into one account. What such accounts implied, rather, was that the principals who commissioned him constituted a coherent group, a network of sorts which deserved separate analysis. Thus the indigo sold on commission came from 'Benech L'aîné' and 'Benech de L'Epinay,' while the 'Sugar and Coffee,' was sent by David Lopes and Torrail \& La Chapelle, two firms from Martinique; each account was based on a specific contractual relationship with an identifiable group, not even necessarily specialized in one product, but clearly identifiable within the merchant network erected by Gradis.

The same analysis holds true for ship-related accounts, except that the relationship was non-permanent and linked explicitly to a certain venture. A ship account constituted the perfect illustration of such a venture-based account, since it distinguished a separate group of people, from the captain to the co-investors who helped bankroll the outfitting and the lading, and only for the duration of the venture. Anything pertaining to a ship was thus gathered into one account, or distributed among several accounts if particular subgroups of investors were concerned within the larger framework of the general venture. This explains why in an extreme case three separate accounts existed side by side in the same three months of June- 
August 1755 for the ship Le David, one for the outfitting ('Armement du navire Le David' or 'Navire Le David'), one for its freight ('Cargaison dans le N.re L David'), and one for the goods on board which directly belonged to Gradis and nobody else ('Cargaison Pour n/C dans Le Navire Le David'). Again, the issue was not only the contractual link (investments held in partnership or not), nor the type of activity (shipping), much less the goods concerned (not even listed in this case), but a mix of all elements, which made of each venture a separate, particular item.

Even when Gradis himself sold his goods through commission merchants, this act did not systematically lead to a separate account: whether the principal/agent relationship deserved to be individualized depended on a series of parameters, most of which probably elude us. Thus there were four specific accounts for wine sold on commission. But silverware sold through Almain de Quebec was credited to 'Marchandises générales,' with no separate record kept. The Benechs were dealt with through a common account, as were the two Martinique firms who used Gradis as commission merchant. The relationship was the same in all these cases, but no general rule was applied beyond Gradis's own view of the importance and separate character of the relationship giving rise to a given account. In some cases this relationship was so obvious to our Bordeaux merchant that the name he picked for an account was remarkably poor in information. The case occurred both for personal accounts ('La société compte courant,' 'La société compte de dettes à recevoir à la Martinique' - without Gradis feeling bound to explain which 'société' was concerned exactly) and to venture-based accounts (what exactly was 'Cargaison $\mathrm{n}^{\circ} 7$ ' in 'Marchandises pour la Cargaison $n^{\circ} 7^{\prime}$ ? Were certain unspecified ship accounts, such as 'Le Navire Le Président Le Berton,' outfitting accounts, lading accounts, or ownership accounts?).

The systematic dividing of accounts according to the specific venture, and within it according to complex combinations of contracts and ownership, proves conclusively that 
Gradis did not try to glean a general view of profits by product traded, by type of activity, or by region. This holds true as well for merchandise accounts. There were eleven such accounts, with one of them, 'Marchandises générales,' including (over three months) silverware, unspecified 'divers de Hollande,' 'quincaille,' paper, cinnabar, salt, beef, 'Coity' [coati?], feathers, walnut oil, lentils, and even 'goods from Cork.' But even with more specialized accounts, such as 'Farine' or 'Eaux de vie,' there was no effort to trace a certain batch of goods from the origin through to the sale, which means that buying and selling prices of specific goods could not be compared. Moreover, the costs entailed in trading certain goods were not necessarily recorded in relation to them, as in the following example:

Le Comte de Raymond Dt; à Divers $£ 395$ Pour Le Vin Suivant a luy envoyé par la voye de Horutener \& Comp de Rouen pour faire passer debout a Valogne, à Son adresse Savoir à Vins de talance pr 2 Bques en double futaille $£ 175$ à Vins achetés pour $1 / 3$ à $70 \mathrm{~W}$ le thoneau 35 à Caisse pr 50 Bouteilles vin muscat rouge à 30s $£ 75$ p 50 Bouteilles dt blanc a 30s 75 pr Rabatage des 2 Bques et double futaille 18 pr droits de Sortie arimage \& fraix $17185^{23}$

Here packing and freight costs were credited to Cash, and debited to the personal account of the customer, rather than being listed in the 'Vins' accounts, so that the actual cost of delivering this wine could not be included in the calculation of the profit derived from selling this particular good, nor was it listed separately elsewhere.

The lone cost account identifiable as such, called 'Primes d'assurance,' gathered all insurance premiums paid by Gradis for his shipping; but apparently he decided that separating this particular cost was not worth the trouble, and closed this account into the general Bills payable account on July 21 st, 1755 , only to reopen it the following day, listing a new insurance premium due for an indigo shipment. ${ }^{24}$ Consequently, most insurance premiums found themselves jumbled together with the rest of Gradis's formal debts, while a few others stayed in the corresponding account. Another cost account, 'Fret à recevoir de divers,' listed freight paid by Gradis as a commissioner for others during the year 1754, but it had been closed by the summer of 1755 , reappearing briefly because a mistake had been made in settling it. ${ }^{25}$ Another account, 'Bien de Tallance,' was basically manorial; it individualized 
Gradis's own wine-producing property, with a corresponding account called 'Vins de Tallance' probably identifying the returns of this product. This listing proves that Gradis was indeed cost conscious as a producer, and that his choice not to record his trading costs consistently was not due to ignorance. Costs were worth recording as a producer, because they represented a stable quantity, with direct and easily measurable consequences on profits; costs of specific ventures or relationships, however, varied widely, both quantitatively and in their relationship to profits.

In the end, there were few elements Gradis thought worth recording separately in real or nominal accounts, besides the few goods he traded more particularly, already mentioned, and his wine-producing venture in Talance. A general Profit and Loss account received indiscriminately all profits and all losses from all personal and venture-based accounts, in such a way as to make strategic calculations almost impossible. Cash was listed separately, though as we have seen some commercial paper found its way, for reasons unclear, into the 'Cash' box. ${ }^{26}$ Commercial paper was recorded in the classic Bills payable and Bills receivable accounts, but some of it was included separately in a 'Lettres à négocier' account, of which we know next to nothing; it may have concerned dubious paper which Gradis had identified as such, and was trying to unload. The same can be said of 'Parties en suspend,' which was probably made up of clearly desperate debts. Two accounts, 'Contrats de cession' and 'Contrats d'obligation,' recorded formal purchases and sales materialized by notarized agreements; again, the shape of the relationship created by a given means of payment turned out to be more important than the kind of activity or goods concerned. Only one account could have been said to identify a specific activity and provide a basis to assess its returns, the 'Grosses avantures' account, which listed bottomry loans Gradis had consented to, except that we find another account named 'Grosses avantures données a Cadis par la Voye de Joseph Masson \& C.e.' In other words, bottomry loans were treated somewhat like commission 
merchant relationships, with some of them set apart because of the specific personal relationship through which they appeared, as with the Benechs for indigo.

As shown by the following table, the account book was largely dominated by the personal credit relationships Gradis had built with the people he dealt with. Very little space was left for other issues. Accounting was, first and foremost, credit accounting, and mostly personal credit accounting. Each account was a narrative of a certain relationship, a tool for quantitative or strategic analysis maybe, but on a strictly ad hoc basis: what counted in most cases was the people, or the group of people, who underpinned the activity thus accounted for. The identification of each element worth a separate account (assets specific to Gradis alone, or people being partners with Gradis, or people simply dealing with Gradis, or in a few cases all people entering into a certain kind of credit relationship) was neither a mere matter of legal contract, nor a straightforward result of regional or product specialization, but a complex combination of all these elements, and possibly more. No two accounts were the same, either; each had its own past, its own potential, and possibly its own constraints, so that generalization was largely impossible. What was reflected here was the highly segmented and uneven nature of early modern markets, and the fact that group control of one or other corner of this market, however small, was the best road to success. Each trading effort was thus very much an ad hoc affair, with a specific good or set of goods, in a specific region, along specific routes, all these specificities being summarized and expressed by the set of business associates which would take charge of the trade from its beginning to its end. What counted most, and what was most counted, was with whom who did what; what was being done was only part of the equation.

Table 1: The account structure of Gradis's journal, October 1754 - September 1755 
1.A.b) Assets in partnership or sent on commission

Marchandises de Compagnie

Marchandises pour la Société

Vins au pouvoir de Digues Latouche

Vins au pouvoir de Jonathan Morgan

Vins au pouvoir de Marsan Larreguy

Vins de Compte a $1 / 2$ avec Baillet

1.A.c) Other

Fret a Payer pour le Compte de Sa Majesté

1.B) General credit category

1.B.a) Goods sold on commission

Indigos p Cte de Divers

Sucres \& Caffés p Cte de Divers

1.B.b) Specific subtypes of credit contracts

Contracts de Cession

Contracts d'obligation

Grosses avantures

Grosses avantures données a Cadis Cte Vx

1.B.c) Commercial paper (formal credit)

Lettres \& Billets à payer

Lettres à négocier

Lettres et Billets à recevoir

Lettres retournées a Protest

Parties en suspend

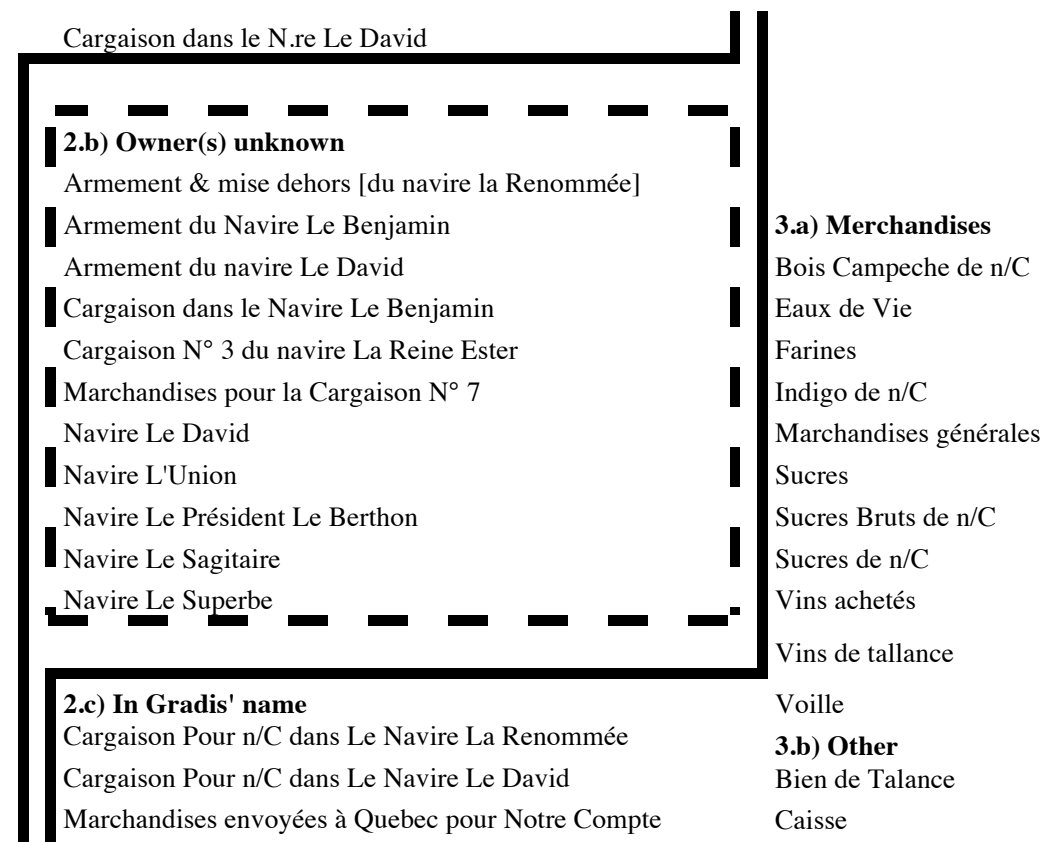

Source: 181 AQ 6* and 7*, loc. cit.

What does Gradis's accounting tell us about his Caribbean operations, and generally about the world he operated in? First, it was a world dominated by interpersonal relationships, but not in the classic Gemeinschaft sense. Making a profit was still the ultimate goal: merchant relationships cannot be reduced to a form of moral economy. The best descriptive tool would be that of the cartel: a group of people bound together by a common economic goal of domination and profit, but among whom solidarity is both the key to success and a fragile construction at best. In some ways, each one of Gradis's accounts was an attempt at cartelization, at building a privileged, protected market access which would bring in profit. In this universe, there was no point in trying to compare two ventures, since each had its own defining characters, from the group of people involved to the institutional environment to use and the physical means of access to control. When Gradis was trading 
with Martinique, the key to success was a good network of planters who would supply him with quality colonial goods, official backing for his trading activities both in Martinique and in the colonial administration in France, and the physical means to bring his goods across the ocean. Trading with Amsterdam meant dealing with a very different group of people. In Amsterdam, Gradis needed Dutch commissioners who would sell his wine at the best possible price, access to Aquitaine winegrowers whose wine would be of good quality, and the monetary means to extend generous credit terms on both sides. Obviously, with each interlocutor the strategies, incentives, and even vocabulary used would be different.

Hence the crucial role of the accounts. Each reflected a privileged relationship, a building block to be used in organizing a profitable access to a certain market. Each was to be treated within the specific context of the relationship for which it had been created. Mere figures were only part of a larger equation, other parts of which were simply not quantifiable. Actually, the figures could take different meaning in context, a point which is made very clear if we try to compare the story line of different accounts. By the summer of 1755, one Lyon merchant, Perrens, owed almost 80,000 Livres tournois to Gradis. Another merchant, Marchand fils, was debitor for 25,000 Livres in the same summer; Bigot, the intendant of Canada, was found to owe 43,000 Livres; and Veuve La Roche, a widow from Girac, owed 842 Livres. Each debt, however, needs to br treated on its own terms. Perrens had been loaned 80,000 Livres by Gradis to buy large amounts of flour, lard, salt and brine, which were then delivered to the king, and the entire sum was at once transferred to the king's account. Perrens was merely Gradis's agent in building up Canada supplies, and the large sums loaned were actually loaned to the king. The account from Marchand Fils was wholly different, since he was a partner with Gradis in the outfitting and lading of the ship Le Sagittaire, and the 23,000 Livres he had received were two IOUs from Gradis acknowledging that Marchand Fils, who was the main outfitter, had paid that much in excess and in Gradis's stead, with the 
latter eventually refunding his partner's loan. In Bigot's case, money belonging to the intendant du Canada was to be deposited in Gradis's account at Chabert \& Banquet, his Parisian bankers, but Bigot had already used it up by drawing on the Parisians, and Gradis was simply acknowledging that Bigot was not a creditor anymore, contrary to what had been assumed at first in his accounts. Of course, in dealing with an intendant, no sensible merchant would have dreamt of pointing out that by drawing on funds which had not yet been deposited, Bigot was in effect borrowing from Gradis, and for free. As for poor Madame La Roche, widow of a business partner of Gradis, she was presumably trying to settle her deceased husband's affairs. She claimed 842 Livres from Gradis, who did not quite agree with her statement of affairs, but who decided to give the sum to her nonetheless, crediting a doubtful debts account ('Parties en suspend') in case the matter were eventually settled which would probably never be the case. ${ }^{27}$

Each sum had its own history, and its own assessment of credit: loaning to the King had its risks and rewards, which were not the same as partnering with a fellow Bordeaux merchant, or humoring a friendly colonial official (who actually partnered with Gradis in supplying his own territory). In at least two cases out of four, Bigot and Veuve La Roche, the rewards were indirect; friendly officials could provide huge comparative advantages, being accommodating with a partner's widow gained one points within one's community, and there would be monetary windfalls eventually. Still, there was in all this a common grammar, a set of rules above and beyond the direct accounting rules, which would enable Gradis, and all other merchants, to compare and contrast their multiple ventures. Each of Gradis's decisions could be assessed - not measured, but judged qualitatively - in terms of enhanced credit, and each credit enhancement could be translated, again in unquantifiable but very concrete ways, in terms of control. Clienteles bred networks, which made access easier, and could turn 
into a decisive comparative advantage over less connected competitors, as in the case of Bigot.

There is a last dimension to Gradis's activity which must be underlined. Counting the sum of all his operations for the 12 months between October 1754 and September 1755 amounts to nearly seven million Livres tournois. The total number of accounts active during the same period was well above 200. An obvious advantage of such a thick and diverse network was risk diversification; Gradis was too big to fail, not because of the size of his operations, but because of their variety. A few accounts could turn out to be lost investments, but there were many others from which these losses could be compensated. With hundreds of potential credit sources, a credit crunch was highly unlikely. One bad batch of goods could lead our Bordeaux trader to lose face on one specific market in one town, but he could point to dozens of other markets elsewhere on which he had been a trustful supplier, and his reputation would merely suffer a passing dent.

Power such as Gradis's has implications for the analysis of the wider early modern economy. Certainly nobody would suggest that markets under the Old Regime were open and transparent. Network-based comparative advantages were turned into bases for monopolization of a market segment, a monopoly sometimes sanctioned by law, as in the case of the various India Companies. Collectively, then, the merchants who held the keys to the various segmented parts of the economy in Europe, the Americas and parts of Asia and Africa were truly a transnational ruling class, with an unassailable position as long as their solidarity held firm, as long as they successfully fended off any drift towards freedom of entry into these multiple niche markets where they made their fortunes. In this way we get back to a regional motif, but under a very different angle; regions existed insofar as they were controlled by a defined subgroup of this international ruling class. It may well be that access to the French Caribbean were dominated by a coherent group of French merchants, but this is 
unclear. At a higher level, the recent general trend towards describing the Atlantic as several more or less nationalized Atlantics may be read as an implicit recognition that nation-based groups of merchants had built exclusive trading spaces which they by and large controlled. But how these groups interacted with institutional realities and other constraints to create more or less exclusive trading spaces, and how rules of interpersonal, account-based behavior were modified under local conditions, are questions to be explored.

On that score, Gradis' example provides only limited support to the idea of a French Atlantic. He operated mostly within the French colonial empire, but was also invested in the Spanish empire, a fact which seems to underscore the relevance of Empire-based analyses. On the other hand, his Caribbean ventures were only one facet of a broad and diverse network, which encompassed France and several other European countries. His was a specifically French operation, both as a royal supplier and as a Bordeaux trader focusing on Quebec and the Caribbean. Notwithstanding these specializations, his accounts stressed personal credit, not national or regional networks. This makes sense since the ubiquity of credit meant that the key to merchant success was a sizeable and trustworthy network of partners, which in the case of Gradis extended well beyond the limits of any one region of the French sphere, and indeed well beyond that sphere. A French trader could favor connections to French planters, French officials and the French Crown; but no trader in his right mind would ever forget that a successful operation depended on cooperation with other traders regardless of nationality, location, religion or ethnic origin. "Frenchifying" or "Atlanticizing" one's operation was always a possibility — but only within limits, and never so far as to structure the way accounts were kept. In the end, the King in Versailles was treated the same way as Jonathan Morgan from Cork, or as the la Pagerie from Martinique, as pieces in a wider puzzle, the shape of which included regional considerations, but was never limited by them. 
${ }^{1}$ Archives Nationales Paris (CARAN), Fonds Gradis, 181 AQ 7* Journal, June 1, 1755 to October 26, 1759. According to the Ordonnance of 1673, the registers had to be certified, and Gradis obtained Agard's certification on May 13,1755. The list of the consuls is available online thanks to AD Gironde, at Inventaire de la série C. Archives Civiles: Tome 3, articles C 4250 à C439.

${ }_{2}^{2}$ Paul Butel, La croissance commerciale bordelaise dans la seconde moitié du XVIIle siècle, (Lille, 1973), Claude Carrière, Négociants marseillais au XVIIle siècle : contribution à l'étude des économies maritimes, (Marseille,1973), André Lespagnol, Messieurs de Saint-Malo. Une élite négociante au temps de Louis XIV, (Rennes, 1997); and for the British Empire, Bernard Bailyn, The New England Merchants in the Seventeenth Century, (Cambridge, Mass., 1955), Cathy Matson, Merchants and Empire. Trading in Colonial New York, (Baltimore, 1998) and David Hancock, Citizens of the World. London merchants and the integration of the British Atlantic community, 1735-1785, (Cambridge, G.-B., 1995). For recent analyses of trade and its importance in the Atlantic, see the special issue on merchant networks published by Annales HSS 58 (May-June 2003); 'Trade in the Atlantic World,' a special section introduced by John J. McCusker, Business History Review 79 (Winter 2005), 697-844; 'The Atlantic Economy in an Era of Revolutions,' a special section coordinated by Cathy Matson, William and Mary Quarterly 62 (July 2005), 357-526; as well as Peter A. Coclanis ed., The Atlantic Economy during the Seventeenth and Eighteenth Century: Organization, Operation, Practice, and Personnel, (Columbia, S. C., 2005).

${ }^{3}$ See John R. Edwards, A History of Financial Accounting, (London, 1989),. For the idea that large-scale, multinational operation brought about a new momentum for innovation as early 
as the end of the eighteenth century, see Gary Spraakman and Julie Margret, 'The Transfer of Management Accounting Practices From London Counting Houses to the British North American Fur Trade,' Accounting, Business \& Financial History 15 (July 2005), 101-119. On the two dominant models of accounting up to the nineteenth century, double-entry and charge and discharge (or 'stewardship') accounting, see Yannick Lemarchand, 'Double entry versus charge and discharge accounting in eighteenth-century France,' Accounting, Business \& Financial History 4 (March 1994), 119-145. For cost accounting, see Fleischman and Parker, What is Past is Prologue: Cost Accounting in the British Industrial Revolution, (New York, 1997).

${ }^{4}$ Daron Acemoglu, Simon Johnson and James Robinson, 'The Rise of Europe: Atlantic Trade, Institutional Change, and Economic Growth,' American Economic Review 95 (June 2005), 546-579; Avner Greif, Institutions and the path to economic modernity: Lessons from the medieval trade, (Cambridge, G.-B., 2006); and for the First Industrial Revolution Joel Mokyr, The Gifts of Athena, (Princeton, N. J., 2002), and David Landes, The Unbound Prometheus: Technological Change and Industrial Development in Western Europe from 1750 to the Present, (New York, 2003 [1969]). See also Pierre Gervais "L'impensé du marché. Approches du développement économique aux Etats-Unis (XVIIIe-XIXe siècles)," Revue de Synthèse 127-2 (Autumn 2006), 299-328.

${ }^{5}$ Jean-Yves Grenier, L'économie d'Ancien Régime. Un monde de l'échange et de l'incertitude, (Paris, 1996); Guillaume Daudin Commerce et prospérité: la France au XVIIle siècle, (Paris, 2005); Philip T. Hoffman, Gilles Postel-Vinay, Jean-Laurent Rosenthal, Des marchés sans prix : I'économie politique du crédit à Paris, 1670-1870, (Paris, 2001); Patrick Verley, L'échelle du monde: 
essai sur l'industrialisation de /'Occident, (Paris, 1997); Pierre Gervais, Les Origines de la révolution industrielle ax Etats-Unis, (Paris, 2004).

${ }^{6}$ A term used (in English at least) primarily for the period 1870-1914, but which has been applied to the European expansion after 1500, particularly in Asia, e. g. G. C. Gunn, First Globalization: the Eurasian exchange, 1500-1800, (Lanham 2003). See also Philip D. Morgan and Jack P. Greene, "The Present State of Atlantic History", Atlantic History: A Critical Appraisal, (Oxford, 2009), 3-33.

${ }^{7}$ On the importance of credit, see Laurence Fontaine, L'économie morale: pauvreté, crédit et confiance dans l'Europe pré-industrielle, (Paris 2008).

${ }^{8}$ I used the edition by Jacques-Antoine Sallé, a lawyer in the Paris parliament, L'Esprit des ordonnances de Louis XIV, vol. 2, Paris: Chez Samson, 1758. The Ordonnance du commerce de 1673 is reproduced pp. $335 f f$. Quotes pp. 355, 356.

${ }^{9}$ Ordonnance du commerce de 1673, loc. cit., Title 1, Articles VII and VIII; Gradis Journal 181 AQ 7*, loc. cit.

${ }^{10}$ Most of these points were made by Basil Yamey, 'The "particular gain or loss upon each article we deal in": an aspect of mercantile accounting, 1300-1800,' Accounting, Business \& Finacial History 10 (March 2000), 1-12; also Hans Derks, 'Religion, capitalism and the rise of double-entry bookkeeping,' Accounting, Business \& Financial History 18 (July 2008), 187-213. See also Pierre Gervais, 'Neither Imperial, nor Atlantic : A Merchant's Eye View of International Trade in the 18th Century,' History of European Ideas 34 (December 2008), 465-473. There are also numerous insights to be found in Pierre Jeannin's various papers, collected in Marchand du Nord. Espaces et trafics à l'époque moderne, P. Braunstein and J. Hoock ed., (Paris, 1996), and Marchands d'Europe. Pratiques et savoir à l'époque moderne, J. Bottin and M.-L. Pelus-Kaplan ed., (Paris, 2002). 
${ }^{11}$ A more exact formulation would be 'the account book of the David Gradis \& Fils partnership,' but in 1754-55 there was only one surviving member of the original partnership, Abraham; his father David and brother Samuel were both dead, and his nephew Moïse was probably not a partner at this early date. See Richard Menkins, 'The Gradis family of eighteenth century Bordeaux: A social and economic study,' unpubl. Ph. D., Brandeis University, 1988, p. 118-121.

${ }^{12}$ Gradis Journal 181 AQ 6* and 7*, loc. cit.; I analyzed in depth 3 months of operations, from June 1st to August 21st, 1755, a total of 386 recorded transactions.

${ }^{13}$ The list of accounts, was derived from both Gradis's journals, covering 12 months from October 1754 to September 1755 (Archives Nationales, Fonds Gradis, 181 AQ 6* Journal, August 1, 1751, to May 31 [not May 14, an incorrect date found in the inventory], 1755, and 181 AQ 7* Journal, loc. cit.). Over this 12-month periods, out of 870 different actors I listed, only 185 were geographically located, barely over a fifth.

${ }^{14} 181$ AQ 7*, ff. 3 recto, June 13, 1755. For accountants, whomever or whatever gives something is creditor, and whomever or whatever receives it is debtor. In our bank statements, we are credited with money given to the bank, and debited with money the bank gives us, because the statement is drawn from the point of view of the bank, confusingly. From the customer's point of view, that is, our point of view, the bank should be debited when we deposit our money (the bank receives, and thus owes) and credited when we withdraw it (the bank gives, and thus is due credit).

${ }^{15} 181$ AQ 7*, ff. 9 verso, July 28, 1755.

${ }^{16} 181$ AQ 7*, ff. 5 recto, June $27,1755$.

${ }^{17}$ See the following posting, from December 24, 1754, 181 AQ 6*, ff. 221 verso:

Caisse Reçu en arg.t $£$ 13538.19.4 une Lettre de Change Sur E. Pecholier au 27 ct 5045 un Billet de Barbet par tout Le Courant 160 un d. de P. Cortis idem 260 Billet de droit de notre c.te 1252.2 [sous-total] 
20256.1.4 Lettres \& Billets a Recevoir P les Suivants 1 de P.re Lafargue pble au 15 avril 5035.41 du même 15 Juin 5035.51 de la fitte du pond 15 Avril 5087.21 du dit 15 Juin 5087.21 de Charles la Brue 15 avril 50321 du dit 15 Juin 50321 de D. Bonnafoux 14 avril 5101.15.4 1 du même 14 Juin 5101.15 .4 [sous-total] 40512.3 .8 [total] 60768.5 .

${ }^{18}$ Thus we excluded 'Le chevalier de Beaufremont' and 'Mr de Beaufremont', who could be one and the same, or father and son; or 'La Roche \& Co.,' which appeared along 'Marieu \& Cmp. \& La Roche \& Comp.' as well as 'Vve La Roche,' with no means to make sure that these accounts were different ones.

${ }^{19}$ In areas were metal currency was rare, such as the Colonies, book credit took an even larger place: see William T. Baxter, The House of Hancock: Business in Boston, 1724-1775, (Cambridge, 1945).

${ }^{20} 181$ AQ 7*, ff. 12 recto, August 18, 1755.

${ }^{21}$ A typical example:

Farines Dt; a Marieu \& Comp \& La Roche £ 200 pour Erreur Sur leur facture du 25 may, ou ils ont debité pour 300 Barrils a 50 Sols $£ 550$ devant être $£ 750$

181 AQ 7*, ff. 4 verso, June 27, 1755. No penalty or interest is charged. In this case the error was not Gradis's; but in other occurrences, where he was at fault, no charge is mentioned either.

${ }^{22}$ Actually, one of the transactions recorded in this account included a set of 'Dens d'éleffans,' which means that account titles were not strict categories... 181 AQ 7*, ff. 3 verso, June 18, 1755.

${ }^{23} 181$ AQ 7*, ff. 11 recto, August 7, 1755

${ }^{24} 181$ AQ 7*, ff. 8 verso, July 21 and 22, 1755. Earlier premiums were transferred to Bills payable because Gradis had systematically paid for them with notes of his hand, i. e. IOUs which he would have to pay back eventually. 
${ }^{25} 181$ AQ 7*, ff. 8 verso, August 18, 1755, for freight costs one Leris should have paid for two bales of cotton and a barrel of sugar 'qu'il a reçu l'année 1754,' thus at least 8 months earlier. The entry clearly implies that the non-payment comes from an oversight, and there is no other mention of the corresponding account for the whole year 1755.
${ }^{26}$ See supra n. 16.
${ }^{27} 181$ AQ 7* passim 